\title{
Occupational Health in Advanced Countries in the Next Century
}

\author{
Robert MURRAY \\ President, International Commission on Occupational Health. 1206 Geneva, Switzerland.
}

\begin{abstract}
The gift of prophecy is rare but an attempt is made to forecast some of the developments in occupational health in the next century. People will not change nor will the natural laws or the properties of chemicals. The biological environment may alter significantly as a result of bioengineering. Environmental stresses will be different but the psychosocial responses will remain the same. Many of the current problems of dose-response relationships will be resolved by time and experience, though inevitably new problems will arise. The level of expectation of health will continue to exceed the resources available.
\end{abstract}

Key words: prophecy, occupational health, epidemiology, working environment, health resources.

\section{Introduction}

In my country it is said that the seventh son of a seventh son has the gift of prophecy, but I can lay claim to no such distinction. Indeed, as the first son of a first son I regard myself as being endowed with the gift of hindsight. Yet it is a very tempting and seductive assignment you have given me - to try to look at the world of occupational health as it will be in the next century.

People have always been interested in foretelling the future. Witness the success of fortune tellers since the oracle at Delphian in classical times and the wide range of methods they use. Some are astrologers seeing the future in the stars. The augurs of Rome foretold the outcome of battles by the intestines of chickens. I am told that in Japan it used to be the practice to heat a turtle shell and foretell the future from the shape of the cracks. At the country fairs in England people willingly pay the gipsy to look in her crystal ball. In my own family I had an aunt who had a reputation for telling fortunes from tea cups. I watched her technique and one day announced that I too could tell fortunes. I do not expect you to be as gullible as those upon whom I practised my deception. The secret is to know something about your victims and then to indulge in broad generalizations which in their expectant state they interpret as prophetic insight. I cannot get away with such chicanery here. The best I can do is to draw on my fortyfive years of practising medicine, 37 of them in occupational medicine, together with my interest in history and try to look forward in the light of past experience. I believe that the more you look back the better chance you have of seeing ahead. 
The first thing to be said is that, for as far ahead as it is possible to imagine, mankind will still have the same anatomical and physiological equipment as he has had for the last million or so years. I was fortunate enough to see the caves of Lascaux before they were closed. The cave paintings were done 20,000 years ago and my abiding impression of those primitive artists is of an imagination and intelligence at least as great as my own. In the next hundred years, and maybe in the next 20,000 years I cannot envisage any fundamental change. The veneer of civilisation may be marginally thicker, but eating, drinking, breathing, sleeping and reproduction will not have changed. Nor will working, whatever we may call it.

Some years ago I was asked to present a paper on leisure. I said that I knew nothing about leisure, that I did not have any. But when I came to think about it, the only difference I could see between work and leisure was that work is the time you are paid for and leisure is the time you are not paid for. It bears no relation to the amount of physical or mental activity involved. Some people work harder at their leisure than they do at their work. And if, as I confidently expect in the next hundred years, much of the physical and mental energy expended in 'work' is reduced, then it will have to be increased during leisure. For if you do not use your muscles they will atrophy and if you do not use your brain it will deteriorate. The important thing is to maintain activity, either at work or play, in order to be healthy and to achieve some measure of fulfilment.

In the next century people will still be born, grow into children, adolescents, men and women and then age and die. There will still be the same distribution of height and weight and of dullness and brilliance, manifesting itself at different ages and stages. There will be an occasional Beethoven, Mozart, Shakespeare or Burns; there may even be the odd Praxiteles or Picasso, but in spite of improvements in transplant surgery and unimaginable advances in therapeutics, they too will inevitably die. A few years ago one of my Swedish colleagues said "This is the first generation which expects to be immortal and they are bound to be disappointed". Living will be just as fatal in the 21 st century as it is in the 20th even though the expectation of life at birth may increase very slightly, by a year or two at most.

We are familiar with the medical paradox in advanced countries, that is, that the healthier you are, the more doctors you need. It might also be said that the more doctors you have, the sicker you become. Our increasing competence and sophistication in measurement, diagnosis and therapy has led to a greater expectation of good health but people are not necessarily happier. Moreover, when they die a cause must be found and the cleverer we become at measuring and detecting occupational and environmental influences, the more blame is likely to be attached to some exposure in the distant past. Consequently there is increasing pressure, especially in the United States, but spreading all over the world, to make compensation claims for negligence on the part of employers or product liability in the case of suppliers. In my view this tendency will 
increase into the next century.

I believe that the greatest health problem in modern times, and for the future in advanced countries, is not that too many people are dying too soon but that too many are living too long. This may appear to be a shocking statement from one trained in the art of healing, but those of you who regularly visit old people's homes may have some sympathy with the thought. Whether our successors in the future can grasp this nettle, or society as a whole can arrive at a policy is difficult to say. They must, but it will be an agonising decision.

Faced with these factors our clear duty is to improve the quality of life and work so that, when the inevitable happens, we can say that, as far as was within our power, we tried to eliminate the hazards which make living and working less than enjoyable. Quality, of course, is not quantifiable, but the quality of life in the future will be, in my view, more important than the quantity of death.

\section{The Nature of Occupational and Environmental Hazards}

The hazardous factors in the environment can be divided into physical, chemical, biological and psychosocial and there seems little doubt that any future problems will fall into one or other of these categories.

\section{Physical Hazards}

The physical factors include radiation, noise and vibration, thermal stress, atmospheric pressure changes and the laws of gravity and thermodynamics. So far as radiations are concerned, I cannot envisage any changes in the electromagnetic spectrum, although I have every confidence that, as with other physical aspects of the environment, it will continue to be manipulated and its effects intensified. Apart from the concentration of ionising radiations in radiology and atomic energy we can look forward to new developments, as happened with the laser. Perhaps someone will find means to concentrate and utilize those silent areas between the microwaves and the infra-red region and between the ultraviolet and the x-rays. While there may be technological advances, it is almost certain that there will be new hazards. We will learn more about the human genetic effects of exposure to ionising radiation, though it is to be fervently hoped that we do not learn it as the result of such an event as befell this city in 1945. We may hope that this will give us better guidance on the determination of tolerable limits of human exposure. The effects of strong magnetic fields, such as arise in the vicinity of fusion reactors, have still to be assessed.

The problem of noise will remain with us, with all that this means in terms of defence engineering, but I have a feeling, especially since attending a conference on the subject in Moscow in March of this year that more is yet to be learned about the mechanism of whole body vibration and vibration effects. 
With regard to thermal stress, people are still going to react in the same way to heat and cold. One of the most exciting developments of the next century is going to be the utilization of geothermal energy and this is going to present problems at the limits of physiological capacity and beyond.

Atmospheric pressure changes are going to increase in importance as underwater exploration of ore as well as oil gets under way and as space travel becomes as much of a job as piloting an aircraft is today. A few days ago, at an International Symposium on Aviation and Space Medicine, held at the University of Occupational and Environmental Health, Japan in Kitakyushu, one of the speakers showed a futuristic slide of a space miner working on an asteroid.

The other area of the physical environment relates to the natural laws, those of gravity, motion and thermo-dynamics. I see no possibility of a suspension of these laws in the next century, nor do I foresee any change in human fallibility, either in the boardroom or on the factory floor. Accidents will still arise in industry, transport and the home and if you should think that accidents are not a part of occupational health, may I remind you of a comment by a former Chief Inspector of Factories in the United Kingdom who said that "The most rapid way to ill-health is an explosion".

Road transport accidents will continue to claim their crop of victims. The Incas of South America were regarded as barbarous because of their habit of human sacrifice. How much more barbarous are we who daily make many more human sacrifices to the god of the automobile? Will our successors be able to tackle this problem more effectively than we have been able to do?

\section{Chemical Hazards}

Chemicals will continue to have the same properties as they do today. Some will be irritant, some allergenic, some fibrogenic, some carcinogenic, mutagenic or teratogenic. Some will be toxic and some will produce skin disease. The upsurge in the science of immunology will lead to the discovery and identification of new allergens. I am not so worried about new fibrogens, because I believe that we know enough about fibrogenesis to forestall any such effect in man.

The greater problem will be those substances which may be carcinogenic, mutagenic or teratogenic. Apart from the human experiments that have been and are still being done, albeit unknowingly, our knowledge of these effects has to be extrapolated from animal investigations. Some critics have said that the object of these experiments is to make the world a safer place for rats! The same critics might well say that the latest bacterial predictive tests have the object of making the world a safer place for Salmonella typhimurium!

I believe in human epidemiological evidence, although I believe equally in doseresponse relationships, and I know from experience that some carcinogenic substances can be handled safely. Soot, for example, will still be as carcinogenic in the next century as 
it was 200 years ago when Percival Pott described cancer of the scrotum in chimney sweeps. But we do not see any scrotal cancer in chimney sweeps today. If I ask for my chimney to be swept it is done by a man with a white coat, who prides himself that he does not get one speck of soot on it. Therefore, he does not get any on his skin.

Toxic substances will demonstrate new or hitherto unrecognised effects and there may well be some nasty surprises such as happened a few years ago with dibromochloropropane (DBCP) which has an adverse effect on spermatogenesis. It is a fascinating speculation to think of what particular organs or systems may be affected by new toxic substances. Dermatitis is likely to remain the commonest of all the occupational diseases. The skin will remain the same kind of organ it is now and will be subject to the same effects, though the causes will vary. In the next century, chemicals will still occur in the form of metals, solvents, plastics, pharmaceuticals, coatings, adhesives, cleaners and polishers and will present themselves as gases, fumes, dusts, or mists. The methods will remain very much as they are now.

Problems of permissible control limits will continue to arise and no doubt there will be the same pressure to lower them as techniques of measurement become more and more sophisticated. One area of chemicals which I believe will assume greater importance is that of smells. I see a great future in the control of smells in relation to their effect on the quality of life.

\section{Biological Hazards}

So far as biological hazards are concerned, they can be divided into three groups; infections, infestations and allergies. As to infections I think the main fear at the present time is that genetic manipulation and bioengineering will result in organisms for which we have not established an immunity.

We know a lot about infestations and I do not envisage any new ones, though the existing parasites will continue to give us plenty of trouble, especially in the Third World. The World Health Organization has now eliminated smallpox but not malaria, bilharzia or hookworm.

As to allergic biological effects, more and more biological allergens are likely to appear, for example as the result of the development of new proteins as animal feeding stuffs by bioengineering methods.

\section{Psychosocial Hazards}

The psychosocial environment of the next century is, I believe, the most vulnerable area of all. We still have the emotional equipment of our cavemen ancestors and although the threats we perceive are different we still react in the same way. No matter what happens, people will still have hopes, fears, ambitions and disappointments. Happiness, satisfaction or fulfilment will continue to be as elusive as they have always been. Doctors will still have to treat the effects and be just as powerless to do more than draw 
attention to their causes.

The difficulty is that man is a social animal who readily forms himself into groups, family, work, social, political or national. The individual contributes something to the group but derives strength from its solidarity. Unfortunately groups do not always pursue the same objectives so that conflict is inherent in the social structure, especially in the working environment.

In this respect I would draw your attention to an article by my friend Ken Tsuchiya on 'Bioethics and Health Care in Industrial Society' (Tsuchiya, 1984). In his conclusion he says "Due to rapid development, industrial society is now required to make a fresh start based on a new type of society which will be able to survive the coming 21 st century. In this situation, health problems must be considered not only by workers in medical science but also by those in other research areas such as economics and technology. The first priority is the establishment of a new ethical standard on bioethics in which Occidental humanism and Oriental humanism are substantially combined. I believe that the establishment of this type of bioethics can lead to a successful institutionalization of health, health care and welfare for the 21 st century".

The English author C. P. Snow, has referred to the two cultures one of science, the other of art, which seem to be mutually antagonistic. I do not believe this to be so. It is probably true that poets and philosophers have had more effect on the future of mankind than scientists and technologists. The scientist improves the physical conditions of life, but the poet enhances the nature of man and widens his philosophical horizons. An Irish poet (O'Shaughessy, 1844-1881) once said:
"We are the music makers
and we are the dreamers of dreams
Yet we are the movers and shakers
of the world forever it seems
We, in the ages lying
In the buried past of the earth,
Built Nineveh with our sighing
And Babel itself with our mirth;
And o'er threw them with prophesying
To the old of the new world's worth;
For earh age is a dream that is dying,
Or one that is coming to birth".

So, while we can look ahead scientifically to changes in the physical/chemical environment, we must listen to the poets and philosophers if we are ever to achieve a real revolution in human behaviour on the lines suggested by Tsuchiya. 


\section{Other Areas of Interest}

Of the many areas of occupational health which could be discussed in relation to the nest century I have chosen only two, epidemiology and administration.

\section{Epidemiology}

One of the striking developments of recent years is the rise of epidemiology. Statistical speculations are made in the light of existing evidence about the relative risks of a wide variety of occupational activities. The essence of the problem is that many diseases have a long latent period, particularly cancer, and recommendations with regard to the action to be taken have to be made on the basis of inadequate clinical evidence of the dose-response relationship.

But in 50 years time we will have evidence on many exposures. Take the case of asbestos. The disease of asbestosis was recognized at the beginning of this century by a certain Dr Murray. For nearly 30 years it was regarded as a medical curiosity. After all, people were dying of tuberculosis or pneumonia in the pre-antibiotic age. Even in relation to other pheumoconioses it was not regarded as anything like so serious as silica.

It was not until 1947 that the evidence for its relationship to bronchial cancer began to accumulate and the first epidemiological study was done in 1955 by Sir Richard Doll. Then in 1960 Dr. Wagner in South Africa described mesothelioma of the pleura and peritoneum in relation to crocidolite. The 1960's saw an explosion of scientific interest in asbestos-related diseases and many epidemiological studies were done. In the absence of any long term data about dose and response, stringent standards were laid down. I can understand the pressure to impose high standards but my personal feeling is that there has been emotional over-reaction to asbestos and that the preventive work which was already being done in the 1950's and 60's by people like myself has not yet had time to manifest itself. For example, mesothelioma has a minimum latent period of 20 years so that the earliest time we can expect to see a downturn in the incidence of the disease is 1986 and it will be into the 1990's before the improvement is obvious to all.

Since the 1950's records have been kept of dust exposures and by the beginning of the next century there will be first class statistical information about the effect of different levels of exposure. I venture to predict that no cases of asbestos-related disease will be found in school teachers or other people whose only exposure has been that they have spent a large part of their time in a building insulated with asbestos.

The same can be said of lead. Lead has been a poison since ancient times and its effects have very largely been brought under control by traditional industrial methods. The fear remains, however, that small doses of lead affect the developing intelligence of children and the media have produced a great deal of unjustified fear.

I believe that in the next 20 years sufficient evidence will have been gathered to give clear guidance on the measures required to deal with any problem that is demonstrated. 
There are many other concerns at the present time which experience in the next 20 to 50 years will resolve: visual display terminals and their effect on reproduction vinyl chloride and cancer: benzene and leukemia: uranium mining and lung cancer: acid rain. I think we can look forward hopefully to a resolution of these and other current problems, but in a world where the media are constantly seeking for bad new I also look forward to unknown new dangers, real or imaginary.

\section{Administration}

Ever since I worked at the ILO and began to look at occupational health on an international level, I have been fascinated by the fact that half of the countries of the world organise their occupational health programmes through their Department of Health while the other half do so through their Department of Labour. The result is that neither Department, as a rule, is prepared to allocate sufficient resources to the subject because they both have other priorities which they perceive as more important. From what I have seen in this country I would regard Japan as an honorable exception. What other Department of Labour in the world has sponsored a University of Occupational and Environmental Health, Japan such as that at Kitakyushu where I have spent the last few days.

Is it too much to hope that in the next century other countries will follow Japan's example and give to the health of workers the importance which the subject deserves. As an old disciple of the ILO I have a great belief in the principle of tripartitism. Consultation between representatives of government, employers and workers is essential in the resolution of occupational health problems. The pre-condition for success is that each party must share a common objective and that each must be represented by scientists of competence rather than motivated by political considerations.

\section{Conclusion}

When I was a boy of eleven I did a good turn to an old gipsy woman. She looked at my hand and said "You are going to be a professional man. You will travel all over the world and you will live to be 84 ". The first two predictions have come to pass and I therefore have confidence in the third. That means that I shall just see the new century come in. I will not be able to verify any of my predictions and I am prepared to admit that any one of them may be wide of the mark.

One thing I am quite sure of. Whatever the nature of occupation in the next century it will be best served by dedicated people observing work and workers and making clinical judgments or safety judgments - about the interface between the man or the woman and their jobs.

The other thing I am sure of is that we must look at occupational health in the context of health as a whole. Many diseases are multifactorial and we must examine not 
only the occupational factors but all these other influences of environment and life style which are the codeterminants of the ultimate health of any people.

There is no doubt that the level of acceptability of risk will diminish, just as the threshold of complaint will become lower. We can look forward to even more disagreement among experts than there is at present. Moeover, we can cast ourselves in the role of Cassandra and prophesy doom. If no doom arises, then we can say "Is that not a good thing"? If it does arise, we have the comfort of saying "I told you so".

I believe that the answer is education. People should not only be aware of the facts but should be capable of interpreting them. Included should be the channelling of ingenuity into areas of safety and the design of substances and processes for safety reasons rather than for reasons of commercial gain.

One of the most interesting lectures on the subject for many years was Lord Ashby's Jephcott Lecture to the Royal Society of Medicine in 1977 in which he discussed our duty to posterity. He said:

"Most difficult of all, however, is the question: what weight is to be given to the interests of posterity? There is an embarrassing contrast between the reliability of prediction in the physical sciences and its unreliability in the social sciences. There are dangers in taking the very long-term view. Arguments for making a decision about an environmental problem which will not 'mature' as it were, for a century, are inevitably difficult to defend and unlikely to lead to any practical action. It is very difficult to persuade human communities to adapt themselves in anticipation of a hazard which has not yet materialized. Utopias end up in wastepaper baskets. So my rule of thumb in environmental policy making would be to make a decade rather than a century the horizon for most decision making. But let my say in the same breath that this does not mean sacrificing principle for expediency; just the opposite: it means recognition that the choices we make influence the values we come to hold.

I think there are pointers to the kind of practical machinery by which the decision maker on environmental policy can adopt a principle when he is legislating not only for the present but for posterity. He will, of course, have to use 'hunch' in his decisions, but so do his colleagues in other government departments, making decisions on foreign policy or VAT or the health service. But 'hunch' based on principle is more likely to be consistent.

The principle is simply Darwin's demonstration that mankind is an integral part of the grand symbiotic system, and that (to adapt Donne) 'any tree's death diminishes me'. This has to be reconciled with the necessity that nature must be exploited for the needs of society. So we need a social device for achieving the reconciliation. One possibility would be for interest groups (bodies like the Friends of the Earth) to challenge in the courts or at public enquiries proposals which might damage the environment or to comment on draft laws and regulations for protecting the environment. Something like 
this already happens over applications for planning permission, so what I am suggesting would be a refinement and extension of an adversary procedure already familiar to us in Britain, with two important and essential conditions: (1) that both sides in the adversary encounter must have access to similar information and technical expertise; and (2) that the encounter must be conducted in a formal and rational way: as in scientific discussion or in courts of law. The interest groups, in acting as guardians for the environment, would automatically be working in the interests of posterity too; and the decision maker (upon whom of course, the final verdict has to depend) could, from this evidence, assess more reliably the effects of his decision upon posterity".

In the next century, disease, in my view, will continue to expand to occupy an area just greater than the resources available to deal with it, though I believe that we in the biological sciences are likely to be much better at prophecy than our counterparts in economics and politics.

\section{References}

Ashby, L. (1977): Jepchcott lecture. New Scientist, 19th May p. 398.

Doll, R. (1955): Mortality from lung cancer in asbestos workers. Brit. J. Industr. Med., 12: 81-86. O'Shaughnessy A. (1844-1881) The Musicmakers. In: Oxford Book of Verse.

Tsuchiya, K. (1984): Bioethics and health care in industrial society. J. UOEH, 6: 177-191.

\section{1世紀における先進諸国の産業医学}

Robert MURRAY

国際労衝衛生委員会 会長

要旨：予言者などとというものは，この世に存在するものではないが，21世紀における産業医学 の発展予测を試みることにする，人類をはじぬ，自然の法則や化学物質の性質は変化しな いだろうが，生物学的環境は生物工学によって大きく変わると思われる。環境ストレス は異なったものとなるであろうが，人の社会的，心理学的反応は本質的には変化しないで あろう. 量・反応関係についての，現在の問題は，時間上実験により解決されるだろうが， 他の新しい問題が起きるのは避けられない，利用できる資源を越えても健康への期待は止 まることはない。

(これは，Murray 先生が1984年10月25日，広島における全国労働安全衛生大会で口演さ れた原稿を，先生自身が訂正されたものである。)

J. UOEH（産業医大誌），6 (4):345-354 (1984) 